Since the subsidence rate in the peat and muck lands of the California Delta is approximately double that reported in other areas, and since biological decomposition is a major cause of subsidence, reasons for the high decomposition rate were investigated.

Estimates of decomposition in field soils based on ash analyses failed to account for all the subsidence which has occurred, suggesting that considerable soil has been lost by means other than aerobic decomposition of the layers above the ground water level. Other possibilities are wind erosion and anaerobic decomposition below the water table. Appreciable decomposition rates measured in peat incubated under conditions of limited oxygen supply suggest that anaerobic decomposition contributes to subsidence in the field.

Alternate wetting and drying were found to accelerate the rate of decomposition. Immediately after each wetting a high rate was observed, which declined gradually. Mixture of peat and muck soils with mineral soils was found to increase, rather than retard, loss of carbon from the organic soils. This was partly due to the higher $\mathrm{pH}$ of the mineral soils in some instances, but a similar effect was observed when no pH change occurred. Addition of plant residues to peat soils tends to counteract the effects of subsidence, even though normal amounts of residues are insufficient to maintain the soil elevation.

Evidence is presented, which indicates that subsidence rates in the Delta may be decreasing, and may eventually attain values comparable with those reported elsewhere. The experiments suggest that as a means of conserving peat and muck soils infrequent cultivation, high water table, and maximum return of crop residues to the soil are desirable. 


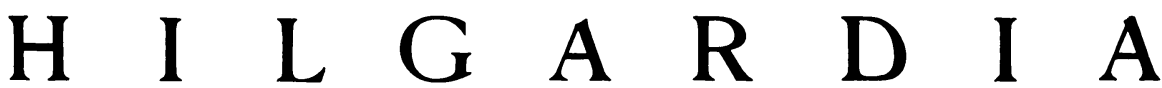

A Journal of Agricultural Science Published by

the California Agricultural Experiment Station

VoL. 29

FEBRUARY, 1960

No. 13

\section{FACTORS INFLUENCING THE DECOMPOSITION OF ORGANIC SOILS OF THE CALIFORNIA DELTA ${ }^{1}$}

\section{F. E. BROADBENT ${ }^{2}$}

\section{INTRODUCTION}

THE FORMATION of peat and muck soils is dependent on the existence of conditions of poor drainage in an area over a long period of time. These conditions are found in lakes, marshes, and delta swamps where the rate of plant growth is greater than the rate of decomposition of plant remains. The reduction of the decomposition rate below the growth rate is a result of the exclusion of oxygen from the surface soil by excess water, since in an anaerobic environment biological decomposition is neither rapid nor extensive. Estimates of the rate of accumulation of organic soils obtained both by pollen analysis and by radiocarbon dating are on the order of 0.002 foot per year, or a foot in five hundred years.

When organic soils are reclaimed and brought under cultivation, it is necessary to change from an anaerobic to an aerobic regime in the surface soil, resulting in much more rapid decomposition rates. This represents a reversal of the conditions which permitted accumulation of the organic soil, and it begins gradually to disappear. This gradual disappearance, termed subsidence, is a characteristic of all organic soils under cultivation and is one of the major obstacles to establishment of a permanent agriculture on peat and muck lands. The oldest records of subsidence in existence, obtained in the Fens in England, show an average decrease in elevation of approximately $1 \frac{1}{2}$ inches per year (Darby, 1940) ${ }^{3}$ Subsidence studies in the Florida Everglades indicate an average annual loss of about 11/4 inches per year (Stephens, 1956). In contrast to these values, the measurements made by Weir (1950) in the California Delta area between the years 1922 and 1948 show the annual subsidence rate to be on the order of 3 inches, or a foot in four years.

Although a certain amount of subsidence is inevitable, the fact that the rate in the California peat and muck lands is approximately double that

${ }^{1}$ Submitted for publication June 1, 1959.

${ }^{2}$ Associate Professor of Soil Microbiology and Associate Soil Microbiologist in the Experiment Station, Davis.

"See "Literature Cited" for citations referred to in the text by author and date. 
reported elsewhere emphasizes the need for investigations to evaluate factors contributing to subsidence, and particularly those relating to biological decomposition.

Weir (1950) has discussed several factors contributing to subsidence of soils in the California Delta, including geologic subsidence of the entire area, compaction by tillage machinery, shrinkage upon drying, oxidation, burning, and wind erosion. Most of the work reported in the literature indicates that oxidation, or biological decomposition, is the major contributor to subsidence, and the experimental work reported in this paper relates to this process. Other workers (Neller, 1944 ; Jongedyk et al., 1950 ; Stephens, 1956) have shown a close correlation between subsidence rate and depth to the water table, indicating that subsidence occurs chiefly in the zone of aerobic decomposition.

\section{ESTIMATES OF DECOMPOSITION IN FIELD SOILS}

Surface soils in the Delta characteristically have the composition of mucks. They are finely divided, contain considerable amounts of inorganic materials, and contain few recognizable fragments of plant remains. Underlying the surface muck is fibrous peat, known as "buckskin," which has a higher proportion of organic matter than the surface soils and contains the remains of tules and reeds. This fibrous peat extends to considerable depths in a fairly uniform layer in many areas. In mapping the organic soils of the region, Cosby (1941) noted: "The occurrence and uniformity of this tule. on-reed peat indicate that for a long time-probably during the entire period of accumulation-the relation between the ground water level and the land surface was more or less constant. The slow and continuous subsidence of the mineral base apparently equaled the slow accumulation of the plant remains. The comparative purity of the reed-formed material which in some places exceeds a depth of 30 feet, tends to support such a theory."

On the assumption that when the peat was originally deposited it was fairly uniform throughout its depth, estimates of the extent of decomposition of the surface layers can be calculated from measurements of the ash content, since organic matter is lost while ash remains. If $a_{0}$ is the ash content of the raw fibrous peat in the subsoil, representing the original ash content throughout the profile, and if $a_{m}$ is the measured ash content of the surface soil, then the percentage decomposition of the surface soil is given by $100 \frac{\left(1-a_{o}\right)}{a_{m}}$, assuming that none of the inorganic material, or ash, is lost during decomposition.

Samples were taken at various depths from soils on Terminous tract and Venice Island ${ }^{4}$ at locations where the depth of the organic soil varied from relatively shallow to very deep. These were analyzed for ash and carbon content, values for which are given in table 1 . All of these samples show that both carbon and ash values are fairly constant down to a certain level, below which the ash content decreases abruptly, and the carbon content increases in a similar fashion. This level apparently corresponds to the

\footnotetext{
${ }^{4}$ The assistance of Alan Carlton in locating the sampling sites and taking the samples is gratefully acknowledged.
} 
average position of the water table, and indicates that decomposition of the peat above the water table is much more rapid than below. Also shown in table 1 are estimates of the extent of decomposition above the water level, calculated on the basis of the ash content of the layer having the minimum value. It will be observed that this reference layer contained 20 to 25 per cent ash and 40 to 45 per cent carbon in nearly every case, which strengthens the assumption that the original peat was of fairly uniform composition. A sample of raw fibrous peat dredged up from a slough at considerable depth was found to contain 20.6 per cent ash and 42.8 per cent carbon, which is in close agreement with the composition of the reference layers of the various profiles. The carbon content of the non-ash constituents is seen to be quite constant with depth and agrees well with that of soil organic matter from other sources, indicating that the carbon content of the organic material changes relatively little with time.

Table 2 shows carbon and ash data for a profile taken on Terminous tract at a location where the soil had not been disturbed for thirty-five years prior to sampling. This site is approximately 2 feet higher in elevation than the adjacent cultivated field, indicating that subsidence was slower, but the data resemble those from cultivated areas in showing a discontinuity in ash and carbon values at the ground water level. Moreover, the calculated decomposition of the surface layers is the highest of any profile. This apparent discrepancy may be partially due to the fact that the uncultivated site was not subject to wind erosion or surface burning, thereby maintaining a higher surface elevation in spite of biological decomposition at a rate comparable with, or even greater than, that in the adjacent field.

In none of the surface soils are the ash contents sufficiently high to account for the actual subsidence which has occurred, assuming that this was due chiefly to biological decomposition of the soil above the water table or to surface burning. For example, Venice Island sample 3 (table 1) would account for a total subsidence of about 26 inches in that profile. In comparison with this figure, Weir (1950) found that Mildred Island subsided 8.32 feet over a twenty-six year period, and presumably subsidence over much of the Delta is of comparable magnitude. Since the ash from this much soil is not found remaining in the surface layers at the present time, a possible explanation is that some of it was lost. Obviously, part of the ash constituents have been removed in crops taken off the land, and some may have gone into solution and moved downward in the profile, although the solubility of the ash is relatively low.

The major constituents of the ash in four soil profiles are shown in table 3. These data are in marked contrast to those reported for ash composition of organic soils in other parts of the United States (Wilson and Staker, 1933 ; Feustel and Byers, 1930) in that the ash of the Delta soils is remarkably uniform, not only as a function of depth but from one soil to another. The ash material is mostly present as acid silicates, having a low solubility. Although the samples taken do not represent any considerable depth of soil, they show no evidence of downward movement of ash constituents as a result of leaching. The ash data give further support to the assumption of uniformity in the original peat deposits. 
The ash values recorded in table 1 are substantially higher than those reported for fibrous peat in other parts of the country, but are fairly comparable with some sedimentary peat samples in this respect (Wilson and Staker, 1933). The high mineral content is consistent with Cosby's view of a constant relation between water level and soil surface. Even the deep

TABLE 1

CARBON AND ASH IN PROFILES OF FIVE ORGANIC SOILS AND EXTENT OF DECOMPOSITION CALCULATED FROM ASH CONTENT

\begin{tabular}{|c|c|c|c|c|c|}
\hline Sample & Depth & Carbon & Ash & $\begin{array}{c}\text { Carbon on } \\
\text { ash-free basis }\end{array}$ & $\begin{array}{c}\text { Calculated } \\
\text { decomposition }\end{array}$ \\
\hline Venice Island No. 1 & $\begin{array}{c}\text { inches } \\
0-4 \\
4-10 \\
10-18 \\
18-36\end{array}$ & $\begin{array}{c}\text { per cent } \\
22.4 \\
21.3 \\
38.8 \\
39.3\end{array}$ & $\begin{array}{c}\text { per cent } \\
\\
54.7 \\
56.2 \\
26.1 \\
25.2\end{array}$ & $\begin{array}{c}\text { per cent } \\
49.5 \\
48.7 \\
52.6 \\
52.6\end{array}$ & $\begin{array}{c}\text { per cent } \\
53.9 \\
55.2 \\
3.5 \\
\text { Reference layer }\end{array}$ \\
\hline Venice Island No. 2 & $\begin{array}{c}0-7 \\
7-13 \\
13-17 \\
17-23 \\
23-30\end{array}$ & $\begin{array}{l}31.1 \\
30.4 \\
31.1 \\
42.6 \\
39.9\end{array}$ & $\begin{array}{l}40.0 \\
40.7 \\
40.8 \\
23.4 \\
29.1\end{array}$ & $\begin{array}{l}51.8 \\
51.2 \\
52.6 \\
55.6 \\
56.3\end{array}$ & $\begin{array}{c}41.5 \\
42.5 \\
42.7 \\
\text { Reference layer }\end{array}$ \\
\hline Venice Island No. 3 & $\begin{array}{c}0-4 \\
4-8 \\
8-14 \\
14-19 \\
19-26\end{array}$ & $\begin{array}{l}30.0 \\
29.7 \\
28.7 \\
43.5 \\
45.6\end{array}$ & $\begin{array}{l}43.6 \\
43.7 \\
46.0 \\
20.6 \\
17.2\end{array}$ & \begin{tabular}{l|}
53.2 \\
52.7 \\
53.2 \\
54.8 \\
55.0
\end{tabular} & $\begin{array}{c}60.5 \\
60.6 \\
62.6 \\
16.5 \\
\text { Reference layer }\end{array}$ \\
\hline Terminous tract No. 1 & $\begin{array}{c}0-4 \\
4-8 \\
8-14 \\
14-18 \\
18-23 \\
23-29 \\
29-34\end{array}$ & $\begin{array}{l}31.5 \\
31.5 \\
32.3 \\
31.5 \\
41.5 \\
36.0 \\
21.6\end{array}$ & $\begin{array}{l}37.4 \\
37.0 \\
37.1 \\
36.1 \\
25.3 \\
33.4 \\
57.1\end{array}$ & $\begin{array}{l}50.3 \\
50.0 \\
51.3 \\
49.2 \\
55.6 \\
54.0 \\
50.3\end{array}$ & $\begin{array}{c}32.3 \\
31.6 \\
31.8 \\
29.9 \\
\text { Reference layer }\end{array}$ \\
\hline Terminous tract No. 2 & $\begin{array}{c}0-6 \\
6-12 \\
12-16 \\
16-20 \\
20-27 \\
27-32\end{array}$ & $\begin{array}{l}30.4 \\
30.9 \\
30.6 \\
43.7 \\
43.8 \\
43.6\end{array}$ & $\begin{array}{l}41.6 \\
42.2 \\
42.3 \\
19.5 \\
19.5 \\
21.2\end{array}$ & $\begin{array}{l}52.1 \\
53.5 \\
53.0 \\
54.3 \\
54.4 \\
55.2\end{array}$ & $\begin{array}{c}53.1 \\
53.7 \\
53.9 \\
\text { Reference layer }\end{array}$ \\
\hline
\end{tabular}

layers of fibrous peat may be partially sedimentary in character, in that some mineral alluvium possibly was mixed with the organic materials during deposition.

It seems likely that wind erosion was responsible for some of the loss of ash suggested by the data of table 1 , but did not remove either organic matter or ash preferentially, since no fractionation of the surface layer was evident. Estimates of the extent of decomposition based on ash analyses would, of course, be low to the extent that surface soil had been removed by blowing. 
TABLE 2

ASH, CARBON, AND CALCULATED DECOMPOSITION IN A PROFILE ON TERMINOUS TRACT UNCULTIVATED FOR 35 YEARS PRIOR TO SAMPLING

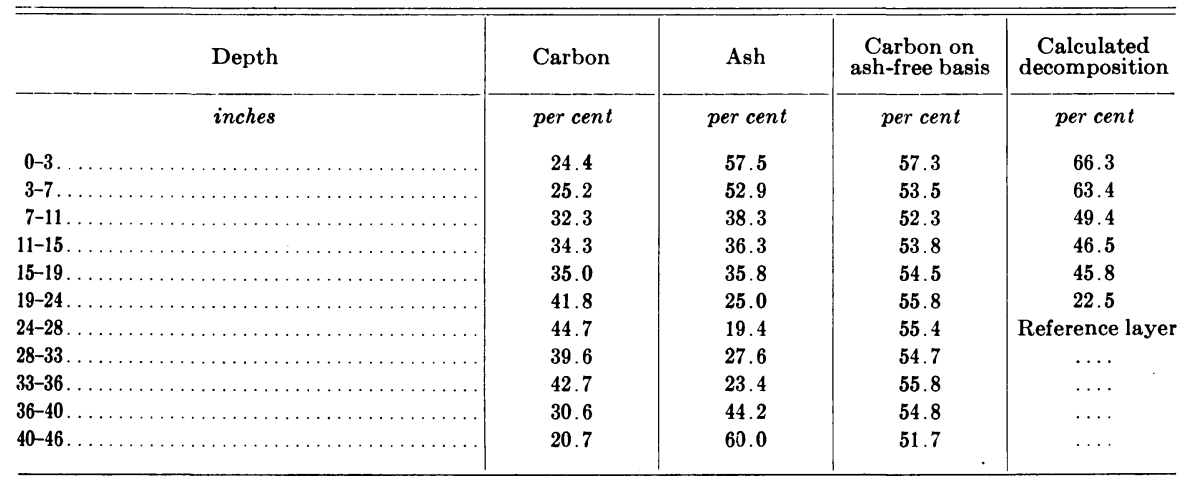

TABLE 3

MAJOR CONSTITUENTS OF ASH IN PROFILES OF FOUR ORGANIC SOILS

\begin{tabular}{|c|c|c|c|c|c|}
\hline Sample & Depth & $\mathrm{SiO}_{2}$ & $\mathrm{R}_{2} \mathrm{O}_{3} *$ & $\mathrm{Fe}_{2} \mathrm{O}_{3}$ & $\mathrm{CaO}$ \\
\hline & inches & per cent & per cent & percent & per cent \\
\hline \multirow[t]{7}{*}{ Terminous tract No. 1} & $0-4$ & 63.7 & 26.5 & 10.1 & 5.9 \\
\hline & $4-8$ & 63.4 & 24.7 & 9.1 & 6.2 \\
\hline & $8-14$ & 63.7 & 25.4 & 9.7 & 6.4 \\
\hline & $14-18$ & 62.2 & 25.9 & 9.1 & 6.3 \\
\hline & $18-23$ & 55.0 & 26.1 & 10.8 & 8.7 \\
\hline & $23-29$ & 65.9 & 20.7 & 8.1 & 6.8 \\
\hline & $29-34$ & 64.4 & 29.3 & 7.2 & 3.0 \\
\hline \multirow[t]{6}{*}{ Terminous tract No. 2} & $0-6$ & 61.0 & 26.5 & 7.5 & 6.2 \\
\hline & $6-12$ & 62.2 & 26.6 & 7.4 & 6.9 \\
\hline & $12-16$ & 62.5 & 26.2 & 7.5 & 6.8 \\
\hline & $16-20$ & 60.1 & 27.7 & 8.7 & 7.7 \\
\hline & $20-27$ & 61.6 & 26.4 & 8.0 & 7.6 \\
\hline & $27-32$ & 60.7 & 28.7 & 7.7 & 6.7 \\
\hline \multirow{5}{*}{ Venice Island No. 1} & $0-7$ & 61.8 & 22.5 & 6.8 & 2.9 \\
\hline & $7-13$ & 61.7 & 21.5 & 6.0 & 3.2 \\
\hline & $13-17$ & 64.0 & 21.0 & 6.1 & 2.9 \\
\hline & $17-23$ & 59.7 & 21.4 & 7.2 & 5.5 \\
\hline & $23-30$ & 62.2 & 22.0 & 6.0 & 5.0 \\
\hline \multirow[t]{5}{*}{ Venice Island No. 2} & $0-4$ & 62.0 & 24.0 & 7.7 & 3.4 \\
\hline & $4-8$ & 63.3 & 18.2 & 5.6 & 2.1 \\
\hline & $8-14$ & 63.9 & 17.3 & 5.6 & 2.3 \\
\hline & $14-19$ & 55.9 & 17.0 & 6.0 & 5.8 \\
\hline & $19-26$ & 66.0 & 20.1 & 6.5 & 6.7 \\
\hline
\end{tabular}

${ }^{*} \mathrm{Fe}_{2} \mathrm{O}_{3}+\mathrm{A}_{2} \mathrm{O}_{3}+\mathrm{TiO}_{2}+\mathrm{P}_{2} \mathrm{O}_{5}$ 


\section{DECOMPOSITION RATES UNDER LABORATORY CONDITIONS}

Effect of Temperature. The high subsidence rate in the California Delta cannot be attributed solely to the mild climate of the region, since the mean annual temperature is at least $10^{\circ} \mathrm{F}$ lower than in the Florida Everglades where the subsidence rate is only half as great. However, to get some idea of the order of magnitude of biological decomposition in Delta soils under winter and summer conditions, laboratory experiments were conducted at $45^{\circ}$ and $75^{\circ} \mathrm{F}$ in which decomposition was measured by loss of carbon dioxide. Figure 1 shows the course of decomposition in Staten peaty muck surface soil and subsoil during an incubation period of almost two months. Carbon loss from the surface soil at $45^{\circ}$ was 40 per cent of that at $75^{\circ}$, and in the subsoil the corresponding figure was 65 per cent. It is interesting to observe that subsoil decomposition was less affected by low temperature than was that of the surface soil. The $10^{\circ} \mathrm{C}$ temperature coefficient, $\mathrm{Q}_{10}$, was 1.7 for the surface soil and 1.3 for the subsoil. These coefficients are comparable with those for other biological processes, indicating that the high subsidence rate cannot be attributed to an abnormally high temperature coefficient of decomposition in these particular organic soils.

Effect of Aeration and Moisture Content. It has been established in other peat areas, principally in Indiana (Jongedyk et al., 1950) and in Florida (Stephens, 1956), that depth of water table is a major factor influencing subsidence rate because most decomposition occurs in the aerobic layer above the water surface. Stephens reported that the relationship between subsidence rate and depth of water table in the Florida studies could be expressed by the equation: $14.77 \mathrm{x}=\mathrm{y}-2.45$, where $\mathrm{x}$ is the subsidence rate in inches per year and $\mathrm{y}$ is the average annual depth of the water table. If this equation is applied to California conditions it can be calculated that the observed annual subsidence rate of 3 inches would require an average water table depth of 46.8 inches, which is somewhat deeper than normally occurs in field practice.

No field experiments have been conducted in the California Delta to show that subsidence is confined to the aerobic layer above the water table, as has been demonstrated elsewhere, and the possibility of appreciable decomposition below the ground water level cannot be ruled out. Waksman and Stevens (1929) found that in lowmoor peat bogs the numbers of aerobic bacteria decreased rapidly with depth, whereas the number of anaerobic bacteria increased rapidly below the water level. Waksman and Purvis (1932) reported that an abundant population of anaerobic bacteria could be found in peat profiles at all depths. Although anaerobic decomposition is inherently less rapid than is aerobic breakdown of soil organic matter, the presence of a large population of anaerobes in peat profiles strongly suggests that some subsidence takes place below the water table.

Several laboratory experiments dealing with the effect of moisture content and oxygen supply on decomposition rates are summarized in tables 4 and 5 . In these experiments small samples (20 to $50 \mathrm{gm}$ ) of soil were incubated in stoppered bottles containing a small tube filled with standard 


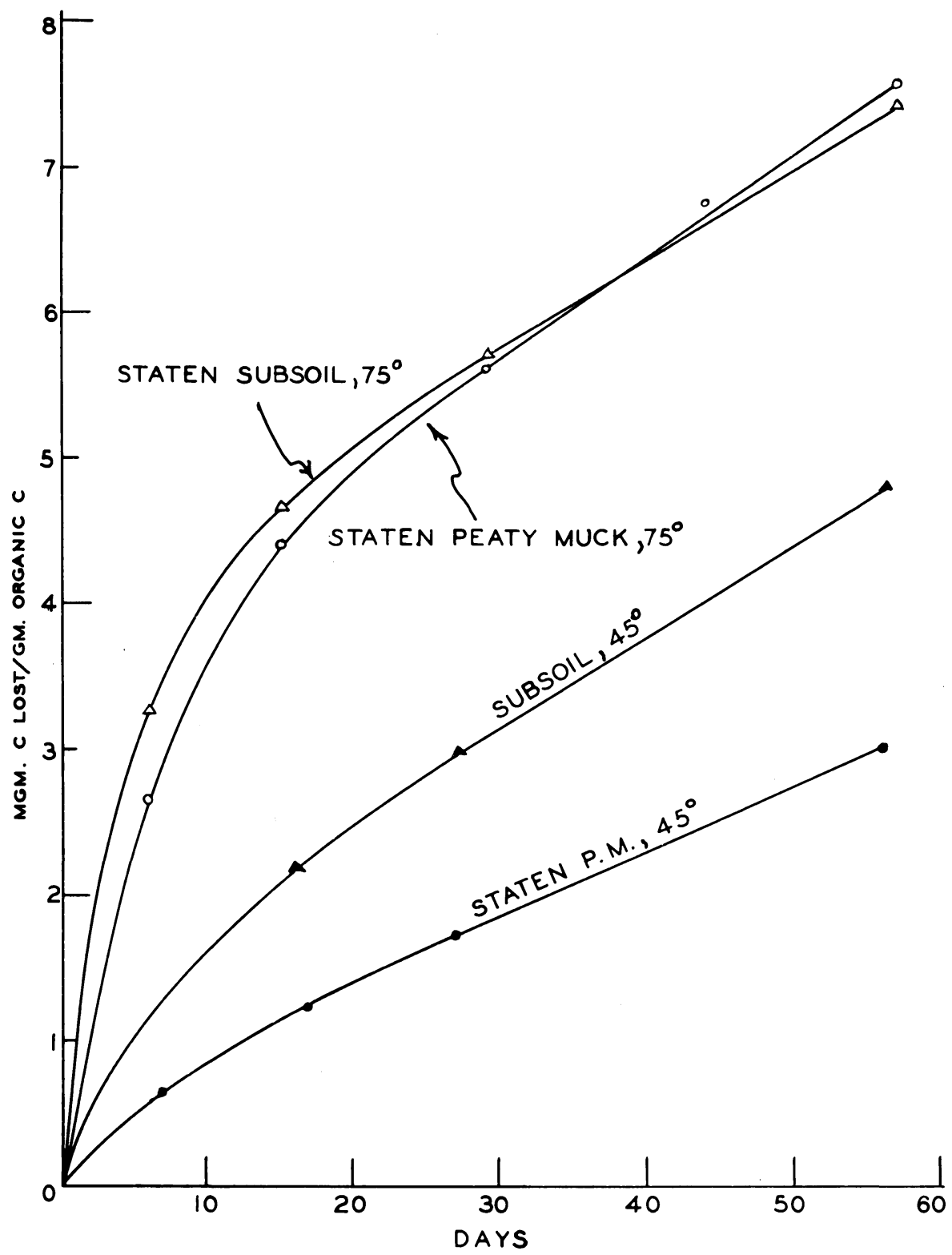

Fig. 1. Decomposition of Staten peaty muck soil samples at $45^{\circ}$ and $75^{\circ} \mathrm{F}$.

sodium hydroxide for absorption of earbon dioxide. The alkali in the tubes was changed periodically and the carbonate content determined. Some of the soil samples were maintained in a nitrogen atmosphere by evacuating to about $50 \mathrm{~mm} \mathrm{Hg}$ and filling with tank nitrogen. The process was repeated three times to flush out residual oxygen in the bottles. The data show that 
samples incubated in a nitrogen atmosphere or in a water-logged condition continued to decompose at an appreciable rate. There was some oxygen in the nitrogen used to maintain an anaerobic atmosphere, which was shown by analysis to be about 0.1 per cent by volume; moreover, in the waterlogged samples the depth of water above the soil samples was only $2 \mathrm{~cm}$, so that some oxygen was undoubtedly supplied to soil microörganisms by diffusion through the surface water. However, even the combination of waterlogging and a nitrogen atmosphere did not entirely suppress carbon dioxide production. In another experiment samples of Staten peaty muck and of raw,

TABLE 4

RELATIVE DECOMPOSITION RATES OF STATEN PEATY MUCK IN AIR AND NITROGEN DURING 57 DAYS INCUBATION AT $75^{\circ} \mathrm{F}$

\begin{tabular}{l|c|c|c}
\hline \hline Soil & $\begin{array}{c}\text { Moisture content, } \\
\text { per cent }\end{array}$ & Atmosphere & $\begin{array}{c}\text { Relative rate of } \\
\text { decomposition }\end{array}$ \\
\hline Surface soil & 100 & air & 100 \\
& 200 & air & 71 \\
100 & nitrogen & 81 \\
& nitrogen & 64 \\
\hline Subsoil & 150 & air & 100 \\
& 350 & air & 79 \\
& 150 & nitrogen & 81 \\
& 350 & nitrogen & 79 \\
\hline
\end{tabular}

fibrous peat were incubated at various oxygen levels by passing gas streams of controlled oxygen content through soil contained in filter tubes. Carbon dioxide evolution was determined by passing the gas through absorption bulbs filled with ascarite, which were weighed periodically. These data, shown in figure 2, agree with the other results in showing appreciable decomposition rates under conditions approaching anaerobism, and surprisingly little difference between rates under conditions of adequate and limited oxygen supply.

The laboratory experiments are perhaps representative of the situation immediately below the ground water level in the field, where considerable decomposition may occur, particularly if the water level is subject to wide fluctuation, but they also suggest that subsidence is not confined to aerobic layers. This possibility is supported by the observation that many of the islands in the Delta are dish-shaped, having a lower elevation at the center where the peat is sometimes, though not always deeper than around the edges where the peat is likely to be more shallow or mixed with mineral material adjacent to the levees. It would be useful to have measurements of subsidence rates in relation to total depth of organic soil as well as depth of water table, in order to evaluate the magnitude of anaerobic decomposition in the field.

Effect of Wetting and Drying. Recently Birch (1958), has reported results of respirometer experiments which show that when a dry soil is moistened an initially rapid period of decomposition is followed by a declining 
rate which attains a slow, steady state after a few days. This pattern is repetitive with successive wetting and drying cycles and appears to be common to all soils. Birch's evidence indicates that the recurrent pattern of decomposition is due to the high metabolic activity of organisms in their physiological youth following the wetting process, and a decline in activity as the population becomes older. Organisms which survive the drying process either as spores or dormant cells are available for multiplication upon rewetting and the cycle is repeated. This pattern of decomposition has an important bearing on estimates of organic matter loss obtained in laboratory

TABLE 5

RELATIVE DECOMPOSITION RATES OF

VENICE PEATY MUCK AS A FUNCTION

OF MOISTURE TENSION DURING 21 DAYS

INCUBATION AT $75^{\circ} \mathrm{F}$

\begin{tabular}{c|c|c}
\hline \hline $\begin{array}{c}\text { Depth, } \\
\text { inches }\end{array}$ & $\begin{array}{c}\text { Moisture tension, } \\
\text { cm of water }\end{array}$ & $\begin{array}{c}\text { Relative rate of } \\
\text { decomposition }\end{array}$ \\
\hline $0-4$ & 50 & 100 \\
(above water table & 0 & 88 \\
in the field) & waterlogged & 85 \\
\hline $12-24$ & 50 & 100 \\
(below water table & 0 & 80 \\
in the field) & waterlogged & 77 \\
\hline
\end{tabular}

experiments, since soil samples are usually incubated under continuously moist conditions, whereas in the field wetting and drying occur.

A preliminary experiment was conducted to evaluate the magnitude of differences in decomposition rates of organic soils induced by wetting and drying. One series of 10 -gram samples was weighed into small plastic cups and incubated continuously moist for 60 days; a second series was vacuumdried after 30 days, then incubated for 30 days more; a third series was dried and rewetted at 20-day intervals; and the fourth was dried and rewetted at 10-day intervals. Organic matter loss was determined by weighing the vacuum-dried samples at the conclusion of the experiment. The results in table 6, which include data for a mineral soil for purposes of comparison, show that in all soils incubated for six 10-day periods the loss was greater than in the other treatments, which did not differ significantly from each other.

Further evidence of the wetting and drying effect was obtained by determining carbon dioxide evolution of samples of Staten peaty muck and Egbert muck after drying and rewetting at 6- and 12-day intervals. The curves obtained (figures 3 and 4) are similar to those reported by Birch (1950) in his work with mineral soils, except that the initial decomposition rate upon rewetting fell off very markedly with successive drying cycles in the organic soils. It is probable that the magnitude of the peak rate obtained upon rewetting is influenced by the time and extent of drying. The soils used in these experiments had been in an air-dry condition for several months before use, whereas during the experiment they were vacuum-dried in a 


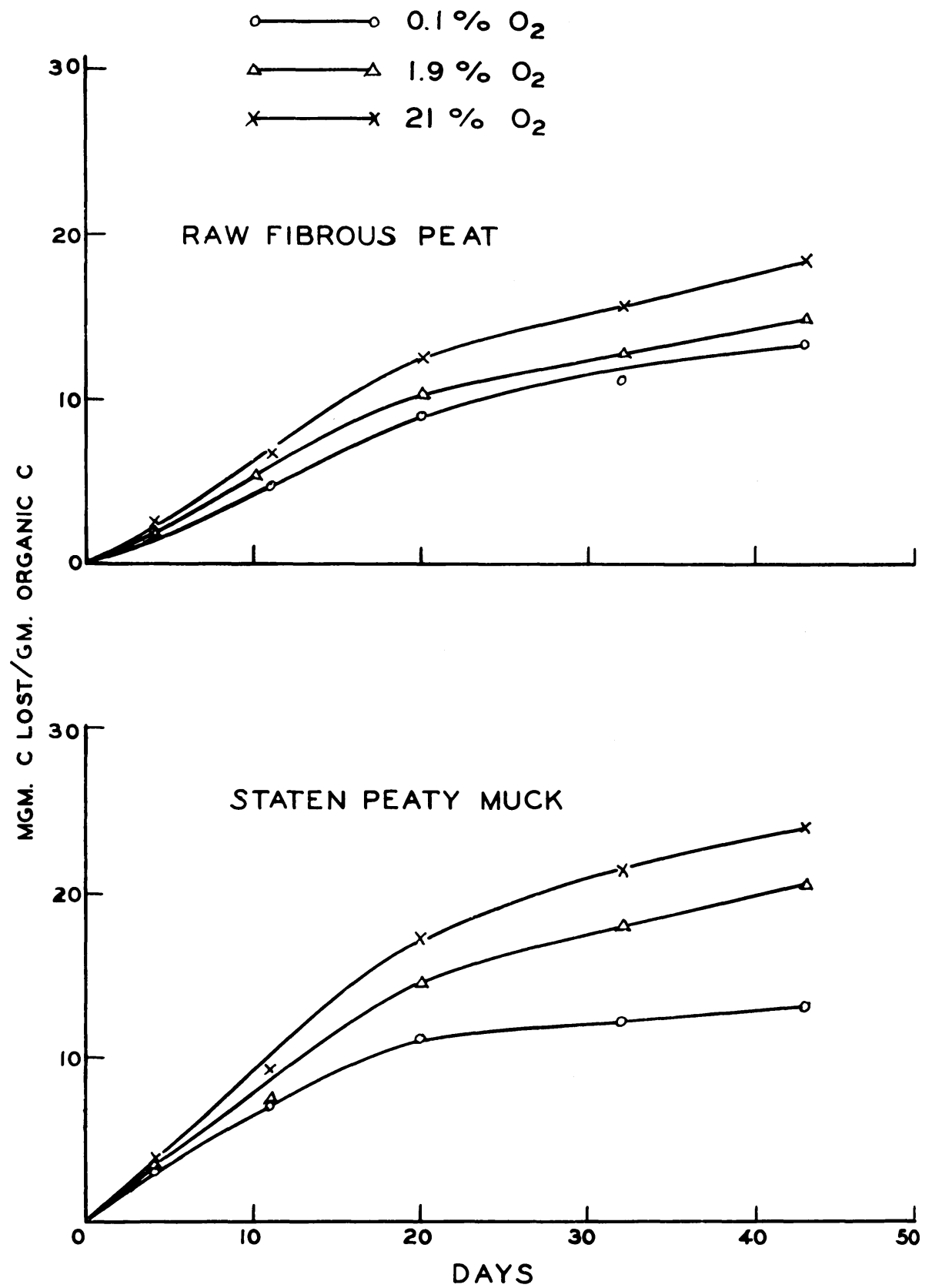

Fig. 2. Decomposition rates of organic soil samples at three oxygen levels. 
matter of 4 to 6 hours and immediately rewetted. Birch found that the decomposition rate is much higher after oven drying than after air drying. Since the decomposition rate is so high immediately after wetting, the number of drying and wetting cycles may influence subsidence quite markedly.

Influence of Mineral Soil Material on Decomposition of Organic Soils. Since the shallow peat soils overlying mineral subsoils at the edges of the Delta area appear to be fairly stable, it seems possible that decomposition

TABLE 6

IJOSSES OF ORGANIC MATTER FROM THREE SOILS DURING 60 DAYS INCUBATION AS AFFECTED BY WETTING AND DRYING

\begin{tabular}{|c|c|c|c|c|}
\hline \multirow{2}{*}{ Soil } & \multicolumn{4}{|c|}{ Periods incubated in moist condition } \\
\hline & $6-10$ day & $3-20$ day & $2-30$ day & $1-60$ day \\
\hline . & \multicolumn{4}{|c|}{$\mathrm{mg}$ O.M. lost/gm C } \\
\hline Sacramento clay.... & 463 & 372 & 357 & 379 \\
\hline Egbert muck ......... & 115 & 89 & 87 & 96 \\
\hline Staten peaty muck $\ldots \ldots \ldots \ldots \ldots \ldots \ldots \ldots \ldots$ & 110 & 90 & 85 & 78 \\
\hline
\end{tabular}

of the organic material in these cases is being retarded by admixture with clay and other inorganic substances. To test this idea, several experiments were conducted to determine decomposition rates of mixtures of organic and inorganic soils. In the first of these, samples from a shallow profile taken on Terminous tract were incubated separately and in combination to determine the effect of mixing the lower horizons, high in mineral matter, with the upper layers of greater organic content. The composition of the various layers (table 7 ) indicates the depth of peat to be about 13 inches, grading into inorganic material of very low carbon content at 2 feet.

The relative loss of carbon is seen to be greatest from the predominantly mineral layer at the 24- to 32 -inch depth. This higher rate of decomposition may have been due in part to the higher $\mathrm{pH}$, but this is of such magnitude that it casts doubt on the idea of protective action due to clay.

Mixtures of the organic 6- to 13-inch layer and the mineral 24- to 32-inch layer were prepared in the proportions 1:1, 1:5, and 1:10 and their decomposition measured in a subsequent experiment. It is apparent (figure 5) that the relative loss of carbon was higher in the mixtures than in the unmixed peat. Similar results were obtained with mixtures of Egbert muck surface soil and its underlying mineral subsoil (table 8).

It appears that the carbon of the mineral subsoil is more reactive, at least during the initial stages of decomposition, than that of the peat. Moreover, the decomposition rate of the peat is accelerated by mixture with the subsoil or, in other words, the observed decomposition rate of the mixture is greater than would have been predicted on the basis of the decomposition rates of the unmixed components. This is illustrated in figure 6 , the data for which were obtained in a 90-day experiment with Egbert peaty muck. It will be noted that although the fraction of the carbon lost from the clay subsoil 


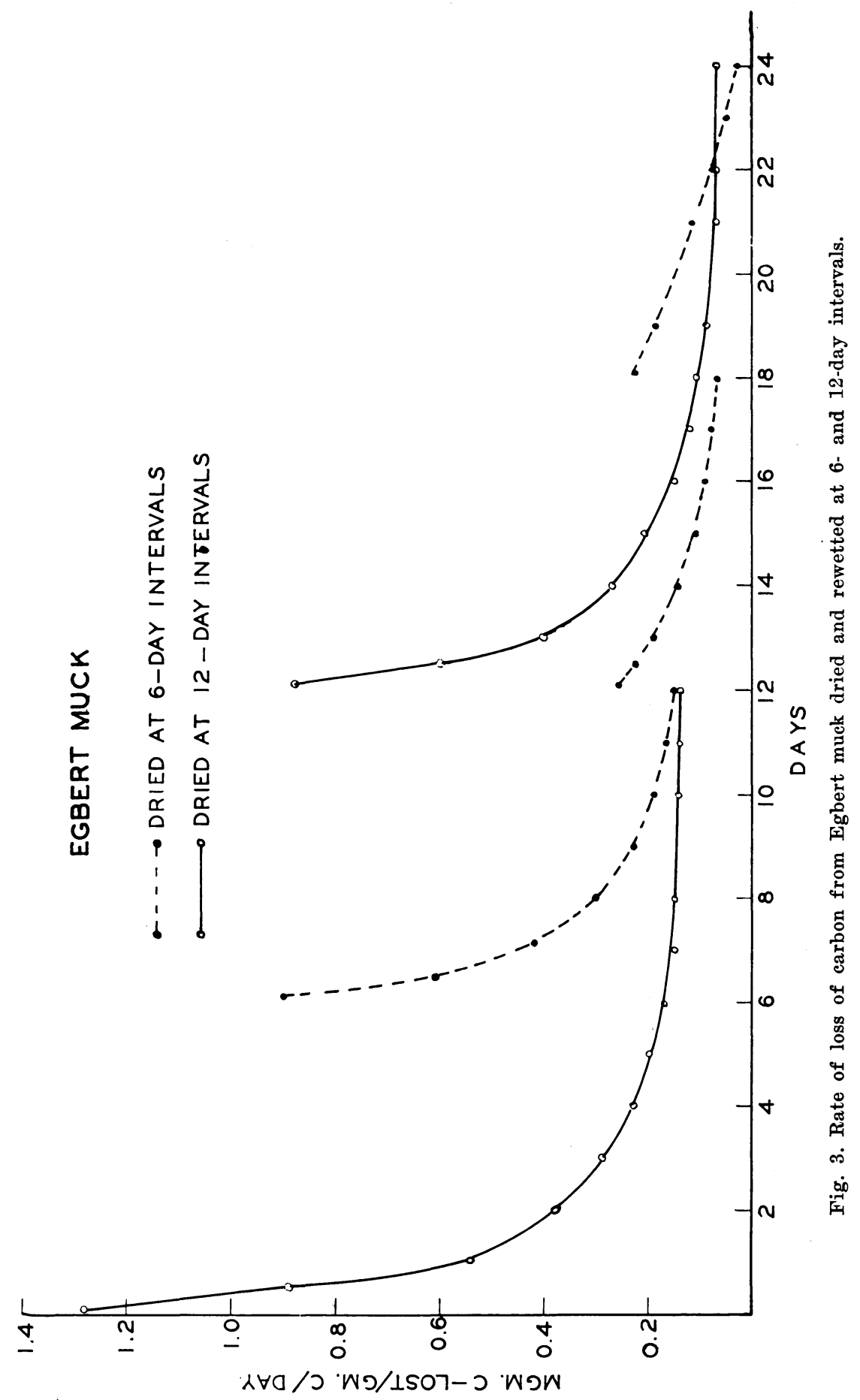




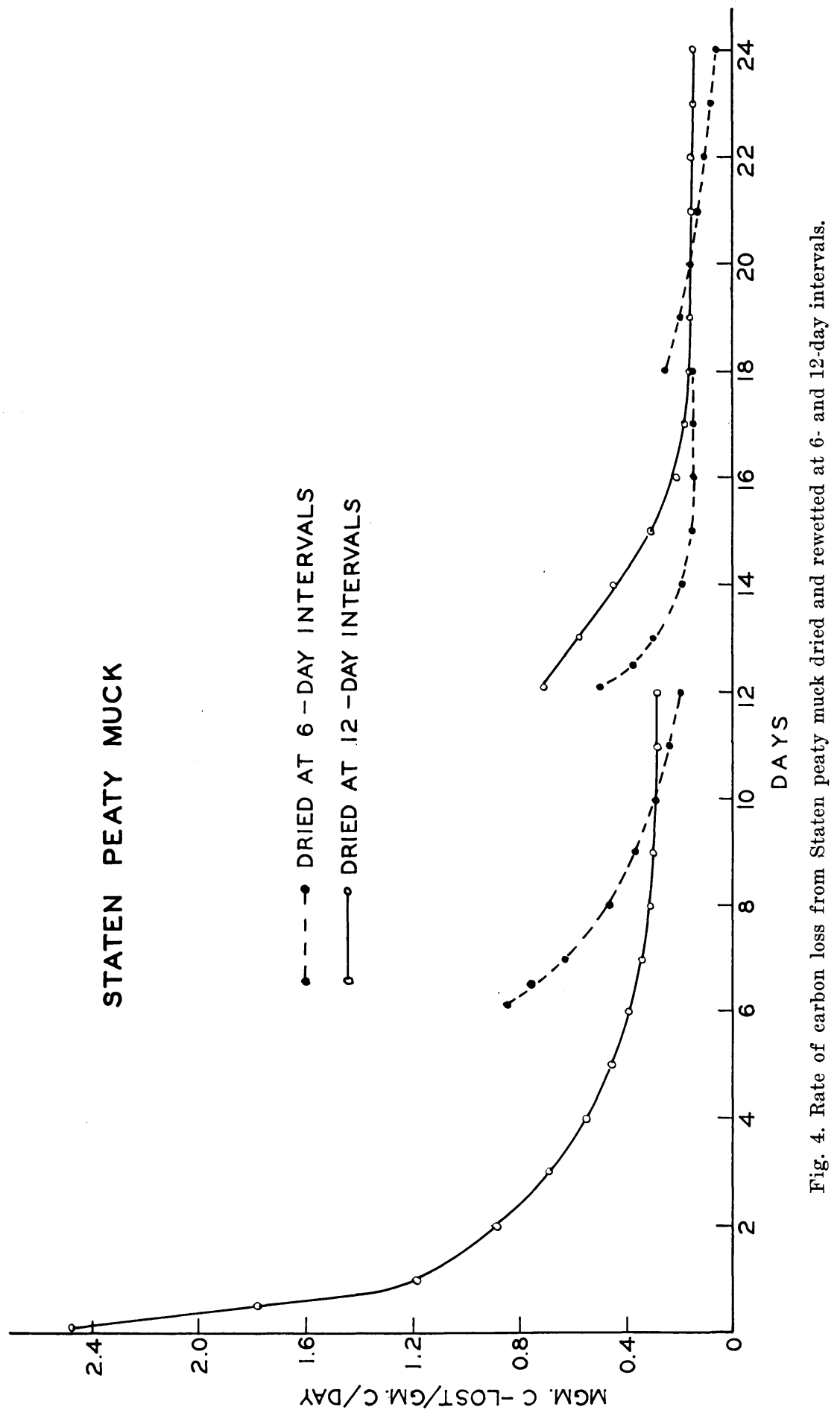


was much greater over the three-month period, the rate of loss had fallen to a very low value toward the end of the period. During the last month of the experiment the surface muck layer sustained proportionally greater loss of carbon than did the subsoil.

Effect of pH. Since most peat soils are acid in reaction, it seems probable that the stimulating effect on decomposition rate produced by mixing peat

TABLE 7

CARBON LOSS OF HORIZONS FROM A SHALLOW PROFILE TAKEN ON TERMINOUS TRACT

\begin{tabular}{|c|c|c|c|c|}
\hline Depth & $\mathrm{pH}$ & Carbon & Ash & $\begin{array}{c}\text { C lost } \\
\text { in } 30 \text { days, per } \\
\text { cent of total }\end{array}$ \\
\hline inches & & per cent & per cent & \\
\hline $0-6 \ldots \ldots$ & $\ldots$ & 27.8 & 45.2 & $\ldots$. \\
\hline $6-13$. & 5.6 & 29.4 & 43.0 & 0.73 \\
\hline $13-20$. & 6.1 & 14.5 & 66.2 & 0.74 \\
\hline $20-24 \ldots \ldots \ldots \ldots \ldots \ldots$ & 6.8 & 3.71 & 92.1 & 0.48 \\
\hline $24-32 \ldots \ldots \ldots \ldots \ldots \ldots$ & 7.7 & 0.70 & 97.0 & 2.50 \\
\hline
\end{tabular}

TABLE 8

RELATIVE DECOMPOSITION RATES OF MIXTURES OF EGBERT MUCK SURFACE SOIL AND SUBSOIL IN 39 DAYS

\begin{tabular}{c|c|c|c}
\hline \hline $\begin{array}{c}\text { Ratio of surface soil } \\
\text { to subsoil }\end{array}$ & $\begin{array}{c}\text { Carbon in mix- } \\
\text { ture, per cent }\end{array}$ & Final $\mathbf{p H}$ & $\begin{array}{c}\text { Carbon lost, } \\
\text { per cent of total }\end{array}$ \\
\hline $1: 0 \ldots \ldots \ldots \ldots \ldots \ldots \ldots \ldots \ldots \ldots \ldots \ldots$ & 15.0 & 6.0 & 0.56 \\
$1: 1 \ldots \ldots \ldots \ldots \ldots \ldots \ldots \ldots \ldots \ldots \ldots \ldots$ & 7.36 & 6.0 & 0.60 \\
$1: 5 \ldots \ldots \ldots \ldots \ldots \ldots \ldots \ldots \ldots \ldots \ldots \ldots$ & 2.71 & 6.4 & 1.20 \\
$1: 10 \ldots \ldots \ldots \ldots \ldots \ldots \ldots \ldots \ldots \ldots \ldots$ & 1.47 & 6.6 & 1.15 \\
$0: 1 \ldots \ldots \ldots \ldots \ldots \ldots \ldots \ldots \ldots \ldots \ldots \ldots$ & 0.51 & 7.1 & 3.41 \\
\hline
\end{tabular}

soil with mineral soil of higher $\mathrm{pH}$ can be attributed in part to the $\mathrm{pH}$ factor. Waksman and Stevens (1929) among others, have reported that liming acid peats invariably increases their rate of decomposition. It is not possible to measure decomposition rates of limed peat soils accurately by means of carbon dioxide evolution unless an isotopic tracer is employed, since a substantial quantity of this gas is released through neutralization of the lime. However, oxygen consumption by the decomposing organisms can be used as an index of microbial activity, although the technique is not so readily adaptable to long-term experiments. A comparison of oxygen uptake by limed and unlimed samples of Egbert muck was obtained in a short-term Warburg respirometer experiment (figure 7). Although the decomposition rate as estimated by this means was almost doubled on the first day as a result of liming, the increase was much less pronounced on the second and fifth days, though still appreciable. These results are typical of those obtained in several other experiments.

The peat and muck soils of the California Delta are not so strongly acidic as are many organic soils in other parts of the country. Few of them have 
$\mathrm{pH}$ values below 5 at the surface, and reactions of 5.5 to 6.0 are not uncommon in the muck areas. Periodic burning of the surface soil has unquestionably contributed to maintaining a relatively high $\mathrm{pH}$. This may have a bearing on the difference between subsidence rates in the Delta and elsewhere.

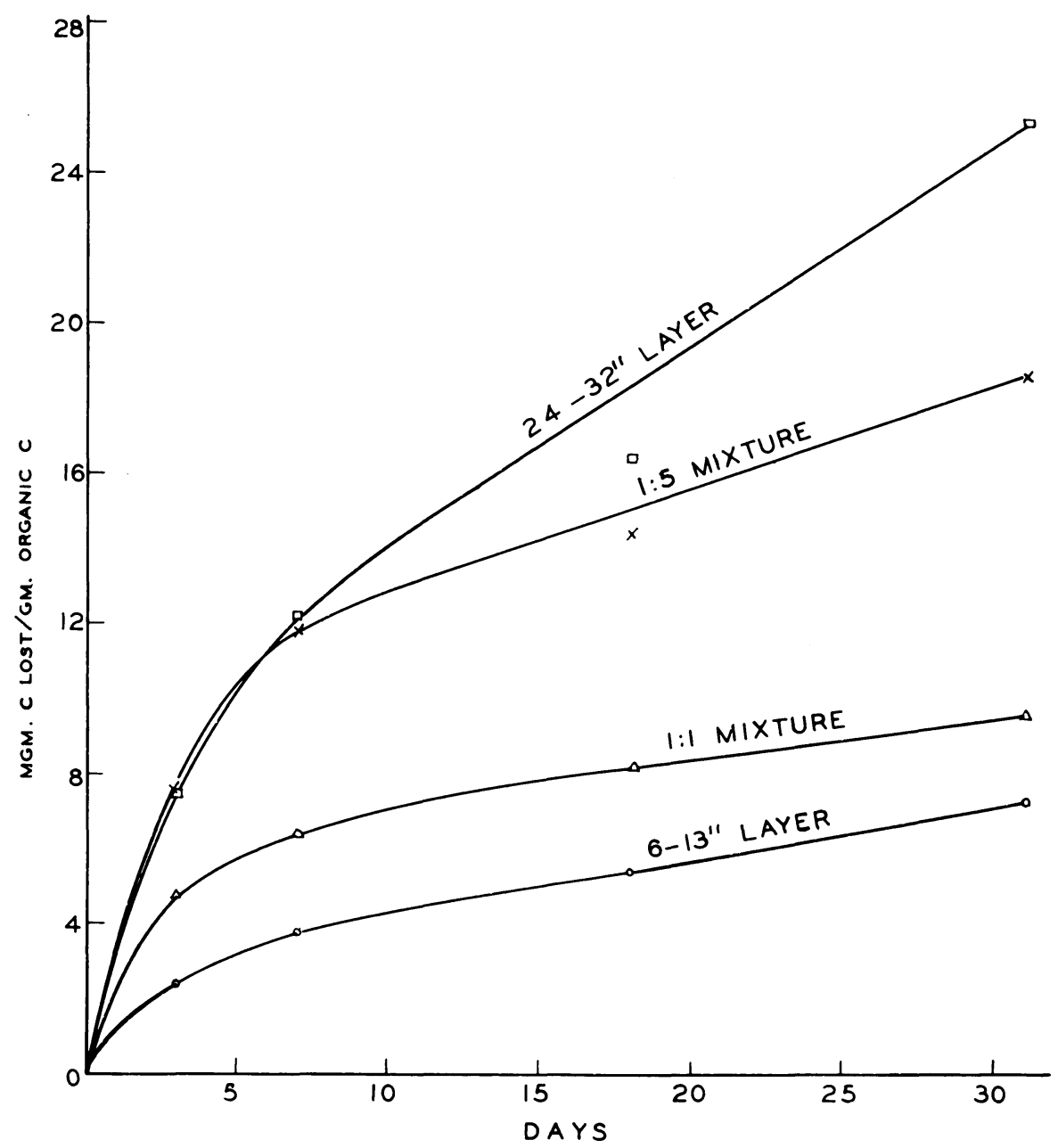

Fig. 5. Decomposition of mixtures of peat and mineral horizons from a shallow organic soil.

In a decomposition experiment involving no $\mathrm{pH}$ change, a sample of Staten peaty muck, $\mathrm{pH}$ 5.4, was mixed with Sacramento clay of the same $\mathrm{pH}$. Again the loss of carbon from the mixture was greater than that calculated from the decomposition rates of the components (figure 8). Where Sacramento clay of $\mathrm{pH} 7.6$ was employed in a similar experiment, the difference between observed and ealculated rates was greater than in the case of the acid clay soil, but qualitatively the results were very similar. These 


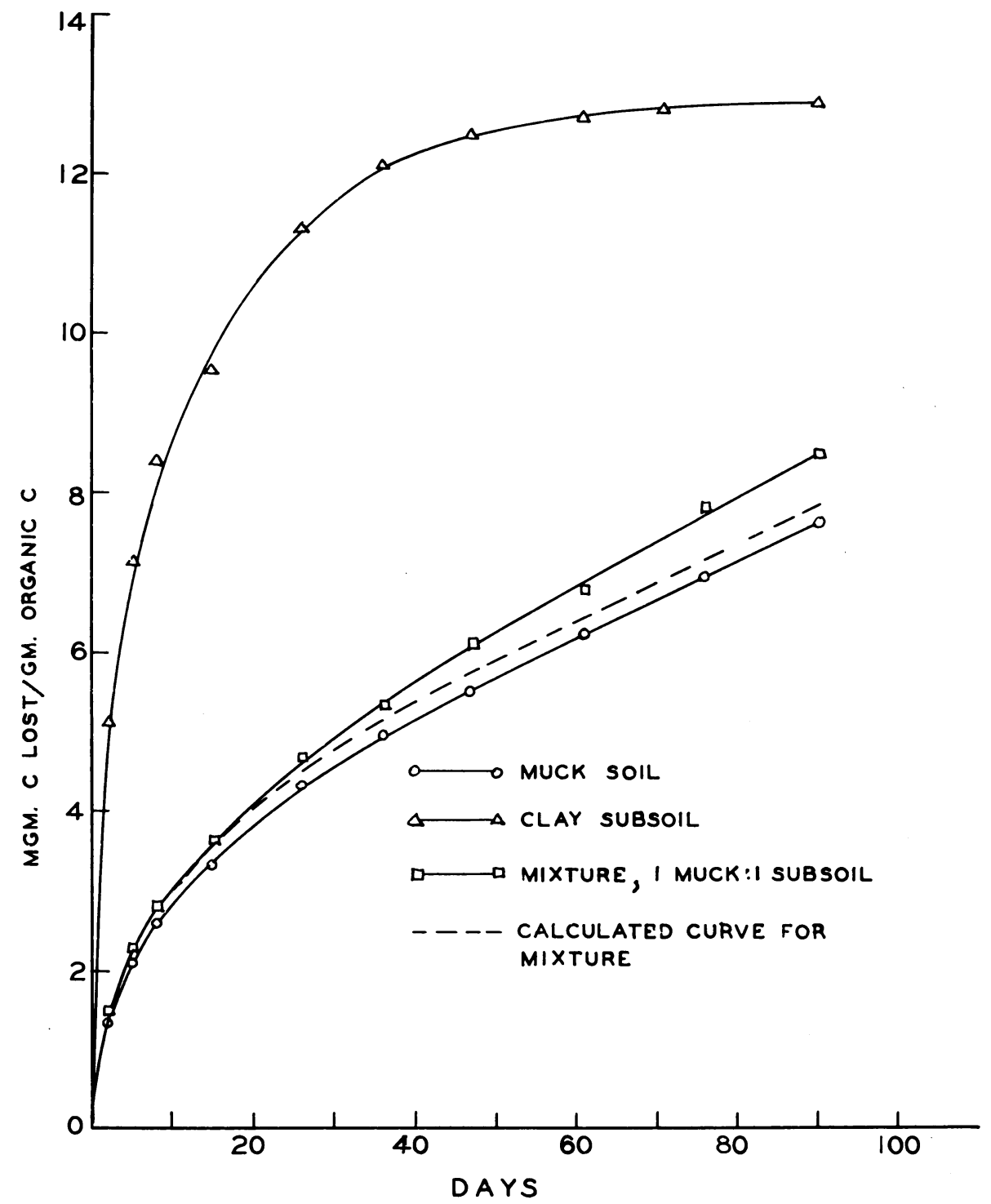

Fig. 6. Decomposition rates of Egbert peaty muck and its clay subsoil incubated separately and in mixture.

findings suggest that mixture of peat with mineral soil is unlikely to be effective in descreasing decomposition rate, whether or not the mineral soil is calcareous. The stability of shallow muck soils at the edges of the Delta would appear to be due to the fact that only a thin layer of organic material is susceptible to decomposition. Their rate of subsidence is low, even though the fraction of total carbon lost each year may be substantially higher than in the deep peat. 


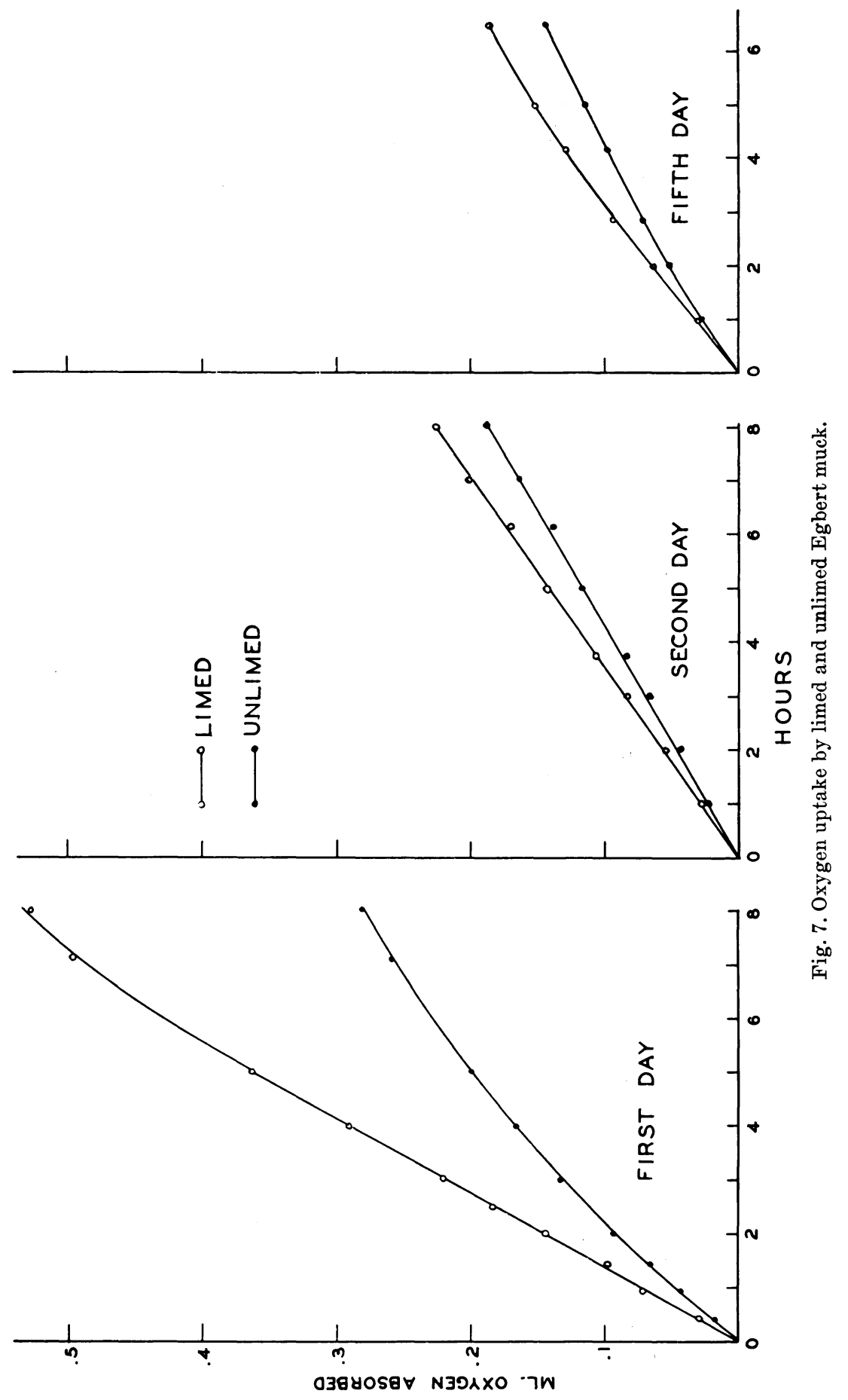




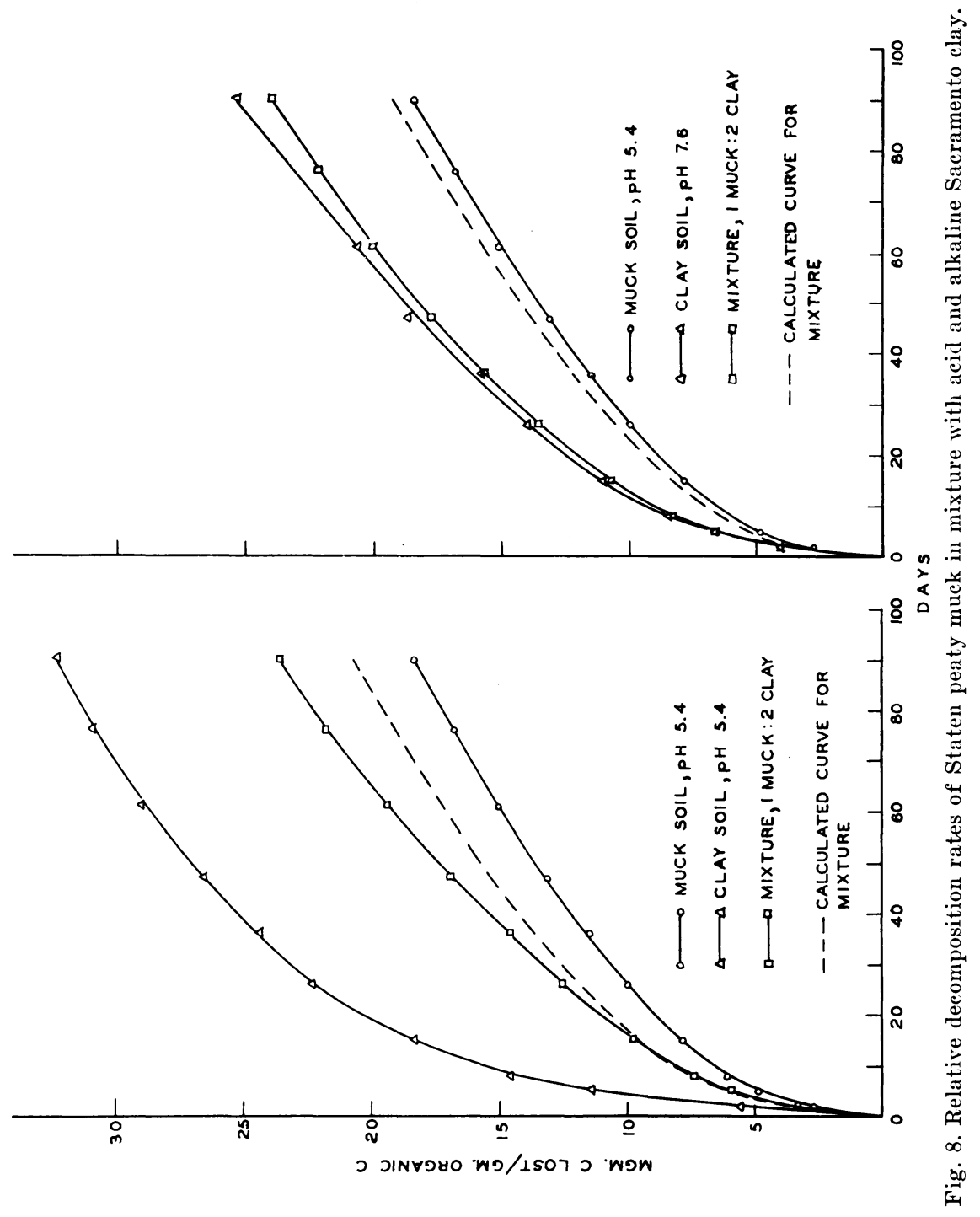


In relation to the effect of soil $\mathrm{pH}$ on decomposition rate, an interesting problem is raised by the presence in the California Delta of a few alkaline peats. It is well known that soil organic matter will absorb oxygen from the air in an alkaline medium. The mechanism of this nonbiological reaction is not well understood, but it results in the conversion of some organic carbon to carbon dioxide. It is possible that this reaction contributes to the subsidence of alkaline peat soils. Figure 9 shows oxygen uptake curves for sterile and unsterile samples of a peat soil of $\mathrm{pH}$ 8.4. Presumably, the oxygen absorbed by the sterile soil was due to the reaction mentioned. A sterilized sample of an acid peat absorbed no oxygen.

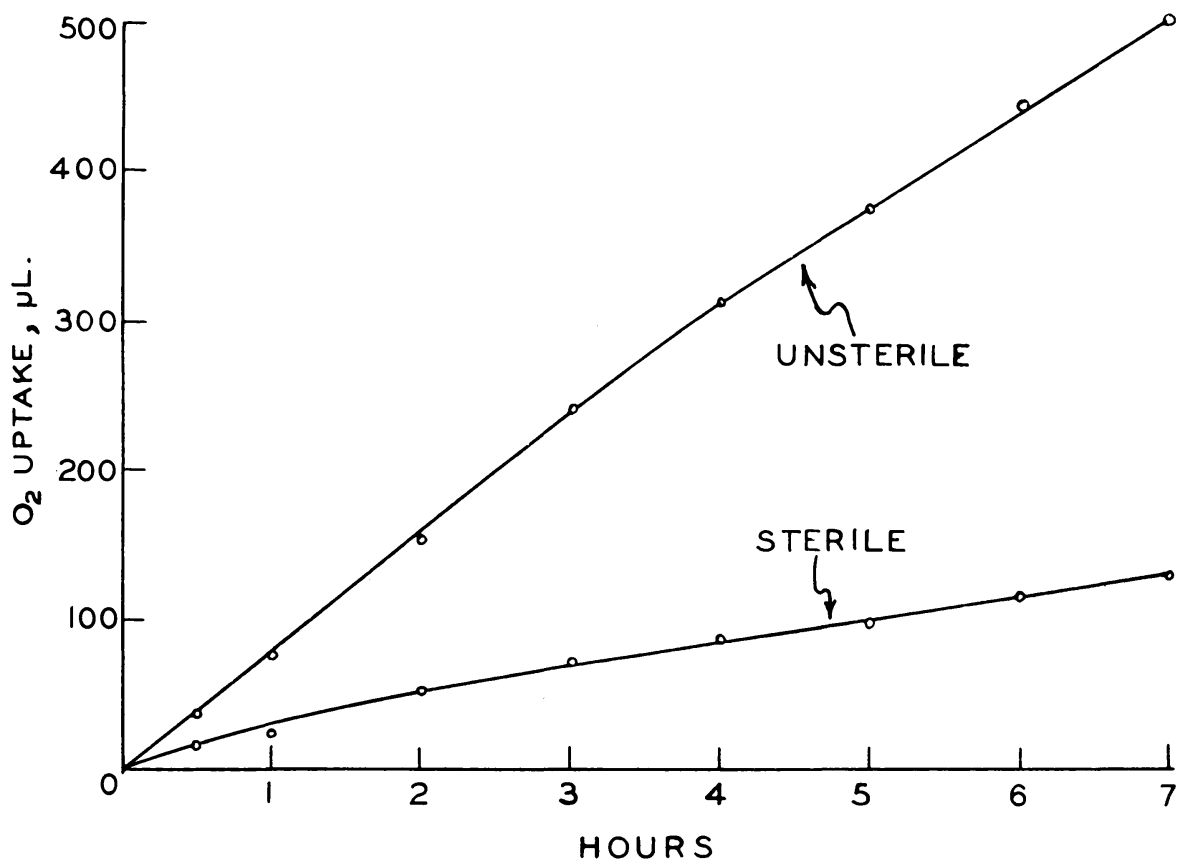

Fig. 9. Oxygen uptake by an alkaline peat under sterile and unsterile conditions.

Effect of Incorporation of Plant Residues. When plant residues are added to mineral soils a large and vigorous microbial population is brought into activity which can attack the so-called humus fraction as well as the plant material (Broadbent and Norman, 1946). Hallam and Bartholomew (1953) reported that plant materials which are easily decomposed accelerate carbon loss more than those which are slowly decomposed, and that the stimulating effect lasts as long as the plant residue constitutes an important part of the decomposing mass. They observed that a net loss of soil carbon may result from addition of readily decomposable residues. In similar experiments with an organic soil Bingeman et al. (1953) observed that easily decomposable materials left a small residue and exerted only a slight "priming action" on decomposition of the soil organic matter. They were able 


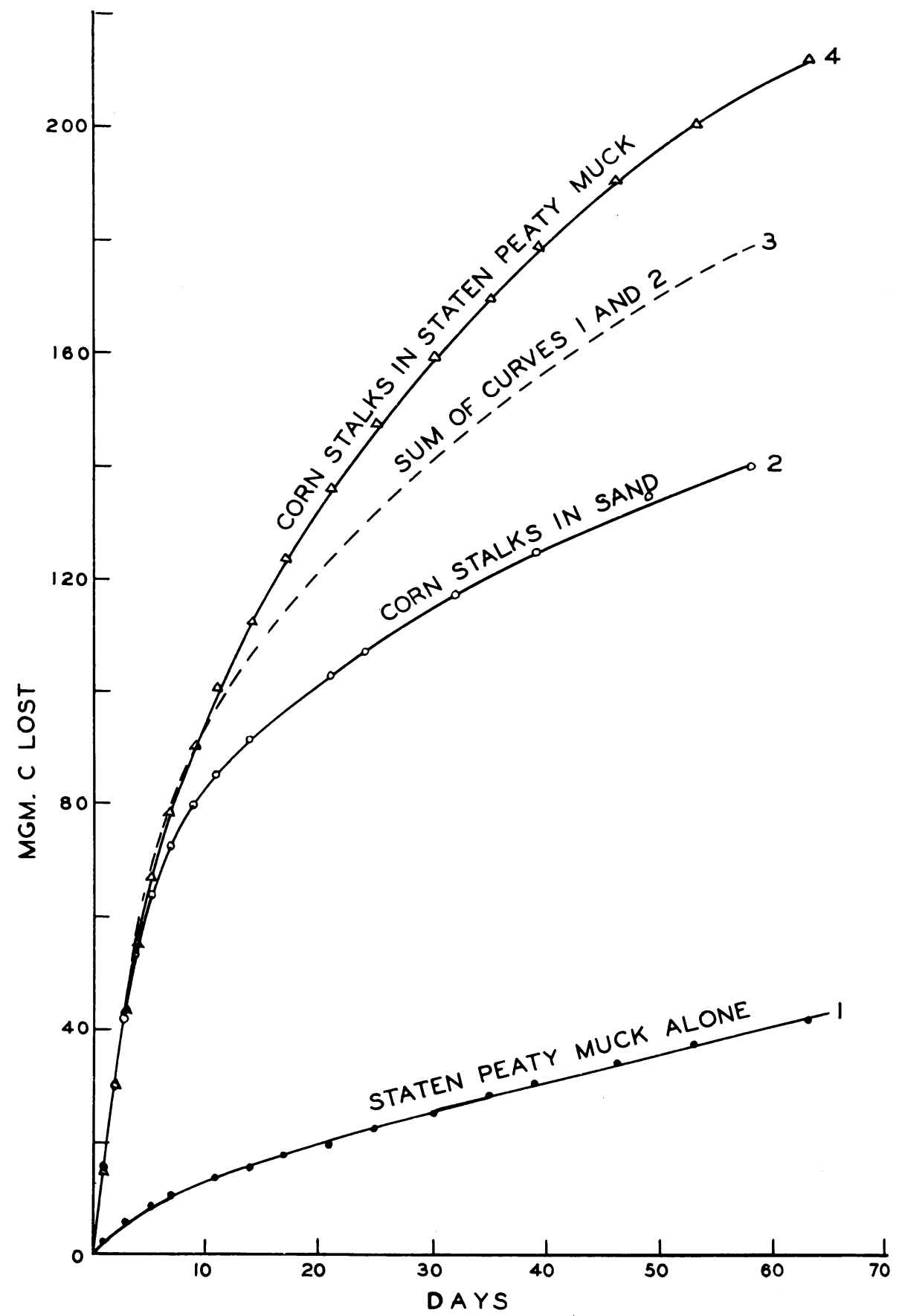

Fig. 10. Decomposition of mature corn stalks in sand and in Staten peaty muck. 
to decrease decomposition losses in a muck soil by the addition of crop residues. More recently, Stotzky and Mortensen (1958) have stated that incorporation of crop residues can be used effectively to decrease subsidence losses in muck soil. Their conclusions were based on 70-day incubation experiments with $\mathrm{C}^{14}$-labeled rye tissue.

The decomposition of mature corn stalks was found to be more rapid in Staten peaty muck than in sand (figure 10), but the total quantity of carbon lost from the mixture in 72 days was only 56.5 per cent of the carbon added. Whether this net increase of carbon would persist after several months' decomposition is uncertain. In this connection it may be noted that the decomposition rate of organic materials added to soils is inversely related to the quantity added, as shown by Broadbent and Bartholomew (1948) in work with mineral soils and confirmed by the experiments of Stotzky and Mortensen (1958) with organic soils. Consequently, frequent, small additions of organic residues may have little effect in counteracting subsidence. The data of figure 10 were obtained from an experiment in which the rate of addition was equivalent to approximately 16 tons per acre, or substantially more than would accrue to the soil in field practice. The loss of carbon from untreated Staten peaty muck in 70 days was equivalent to about 2,800 pounds per acre foot of soil. On the assumption that 20 per cent of the added residue remained after a year's time (37 per cent of the corn stalks was lost in two months) it can be calculated that the subsidence loss in the surface foot of soil would be balanced by a corn stalk addition of 19 tons. Obviously, normal crop residue additions cannot compensate for subsidence losses, although they may reduce them somewhat.

\section{EXTRAPOLATION OF DECOMPOSITION RATES}

Although the laboratory data provide useful information on factors affecting decomposition of organic soils, the results cannot be applied directly to field conditions, particularly in relation to long-term changes. The question arises whether the laboratory results can be extrapolated on any sound basis and, if so, what that basis should be. All the decomposition curves show that loss of carbon is initially rapid after a sample is wetted, then decreases until the rate becomes nearly constant at a low level. In many of the 90-day experiments as much carbon was lost in the first 20 days as in the ensuing 70. The number of drying and rewetting cycles which a soil undergoes will therefore have an important bearing on over-all decomposition, and this is likely to be highly variable under field conditions. Another problem is the diurnal and seasonal fluctuation of temperature in field soils.

Corbet (1934) proposed that the evolution of carbon dioxide from a soil sample in a constant environment could be expressed by the relation $\mathrm{y}=\mathrm{Ft}^{\mathrm{m}}$, where $y=$ total yield of carbon dioxide after the elapse of time $t$, and $F$ and $m$ are constants. He stated that this relationship applied to his data in experiments lasting for several months, although no actual curves were shown. More recently Chase and Gray (1957) observed in respirometer experiments that plots of log rate of oxygen uptake against log time yielded a straight line function, in agreement with the parabolic type of function suggested by Corbet. 
Examination of some of the experimental data reported here indicated that decomposition of organic soils under continuously wet conditions can be reasonably well described by parabolic functions (figure 11). Assuming that these relationships are maintained for a year, the annual loss of carbon from Staten peaty muck is calculated to be 3.04 per cent and from Egbert

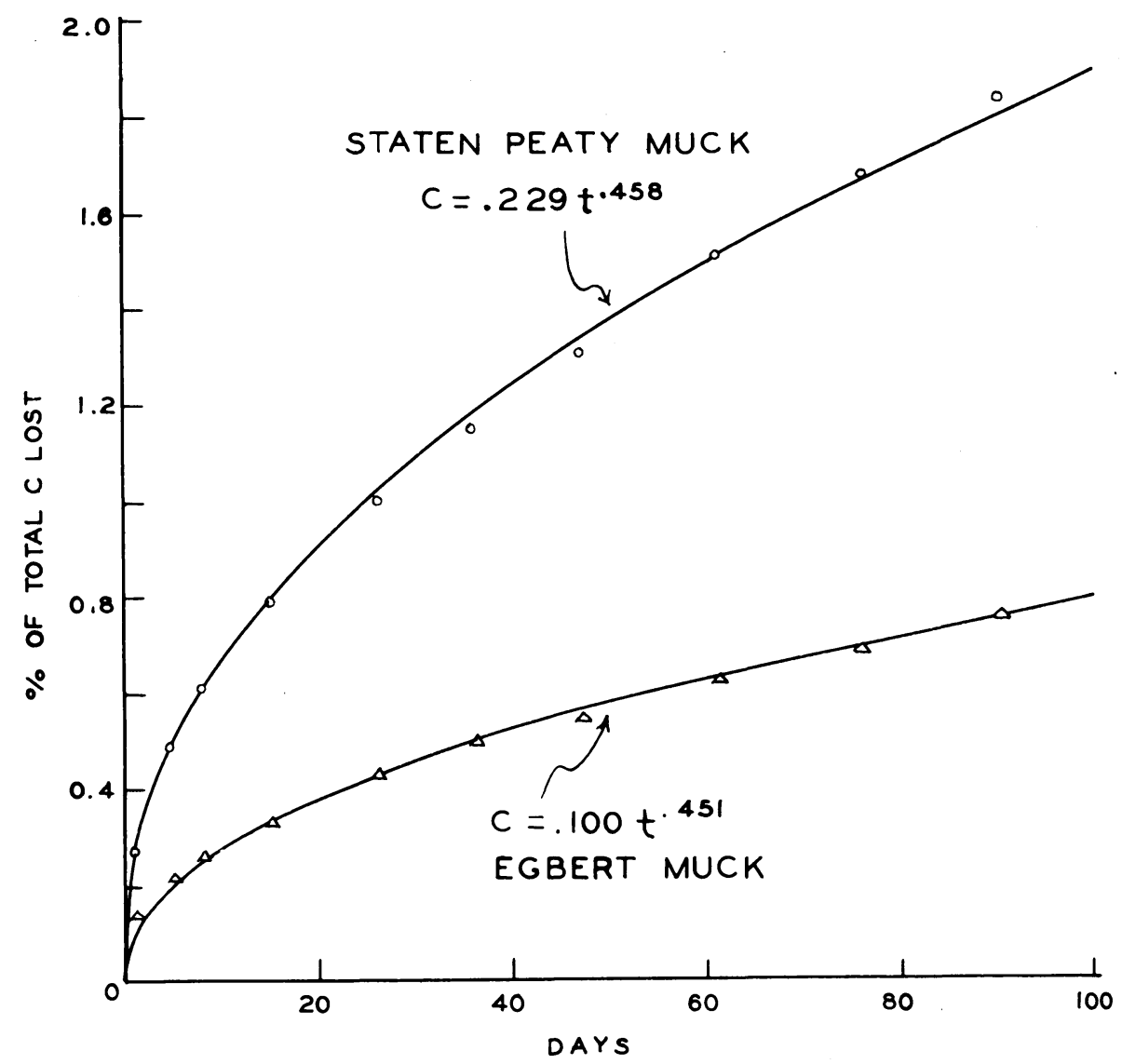

Fig. 11. Parabolic functions describing loss of carbon from Staten peaty muck and Egbert muck. Points are actual data.

muck 1.28 per cent. A linear function for the 60 - to 90 -day points gives a somewhat better fit in the case of the Staten peaty muck, and this extrapolates to a yearly loss of 4.93 per cent of the total carbon. A 5-foot layer of soil decomposing at this rate would subside about 3 inches per year. An annual loss obtained by multiplying the loss in the first 30 days by 12 gives a figure of 13.1 per cent for Staten peaty muck, which is perhaps more realistic, since it is more representative of a series of drying and rewetting cycles. A 23-inch layer decomposing at this rate would account for 3 inches annual subsidence. 
However, it is quite possible that the 3 -inch annual subsidence rate reported by Weir (1950) for the period 1922 to 1948 is not representative of present conditions. When mineral soils of relatively high organic matter content are first brought under cultivation, the rate of organic matter loss decreases in exponential fashion, eventually reaching a value approaching equilibrium. The subsidence of peat in the Florida Everglades has followed this pattern, as shown by the data of Stephens (1956). Weir's measurements of soil elevations on three Delta islands during the years 1922-1948 give no evidence of decreasing subsidence rate, but subsequent measurements made in 1955 and $1958^{5}$ suggest that the rate of loss is declining. In figure 12 , Weir's data have been replotted to show the recent trend. A regression line fitted to the values obtained from 1922 to 1948 on Mildred Island has a slope corresponding to an annual subsidence of 3.6 inches. If this line is extrapolated to 1958 the predicted elevation is found to be 16 inches lower than was actually measured. A parabola fitted to the 1948-1958 data has a slope of 1.42 inches per year at the 1958 point, and predicts that the subsidence rate in 1967 will be 1.03 inches per year on Mildred Island. The corresponding data for Bacon Island show the 1958 subsidence rate to be 1.92 inches per year, becoming 1.17 inches in 1967, forty-five years after Weir's measurements were first made. Additional evidence of a decreasing subsidence rate can be found in the observation that Lower Jones tract, Bacon Island, and Mildred Island had been under cultivation 20, 7, and 1 year respectively before Weir made his initial measurements. He found the average annual subsidence rates during the ensuing twenty-six years to be 2.5, 3.2, and 3.8 inches, respectively. Another interesting comparison can be made if it is assumed that Lower Jones tract and Bacon Island were approximately at sea level when first cultivated, and that both decreased 2 feet in elevation the first year, as Mildred Island did. The average annual subsidence of Lower Jones tract is calculated to be 1.8 inches during the first twenty years, whereas Bacon Island subsided 2.8 inches per year during the first seven years. It may be that the decline in subsidence rate suggested by these figures is due to decreased frequency of burning. In any event, the current rates calculated from the curves of figure 12 are more in line with those reported elsewhere. The State Division of Water Resources is currently undertaking a series of surveys which will furnish more complete information on subsidence rates in the Delta and which will provide a check on the figures projected here.

\section{DISCUSSION AND CONCLUSIONS}

The subsidence of organic soils, being a biological decomposition process, is subject to those factors which have a bearing on the level of microbial activity in soils, including temperature, moisture content, $\mathrm{pH}$, and adequacy of aeration. Although the experiments upon which this paper is based have been limited in scope, the striking thing about the results is that within the limits of these factors which were used, none of them was found to exert a dominant effect on decomposition rate of peat soils, although each of them

\footnotetext{
${ }^{5}$ Used here by permission of $\mathrm{W}$. W. Weir, to whom I am grateful for making these data available.
} 


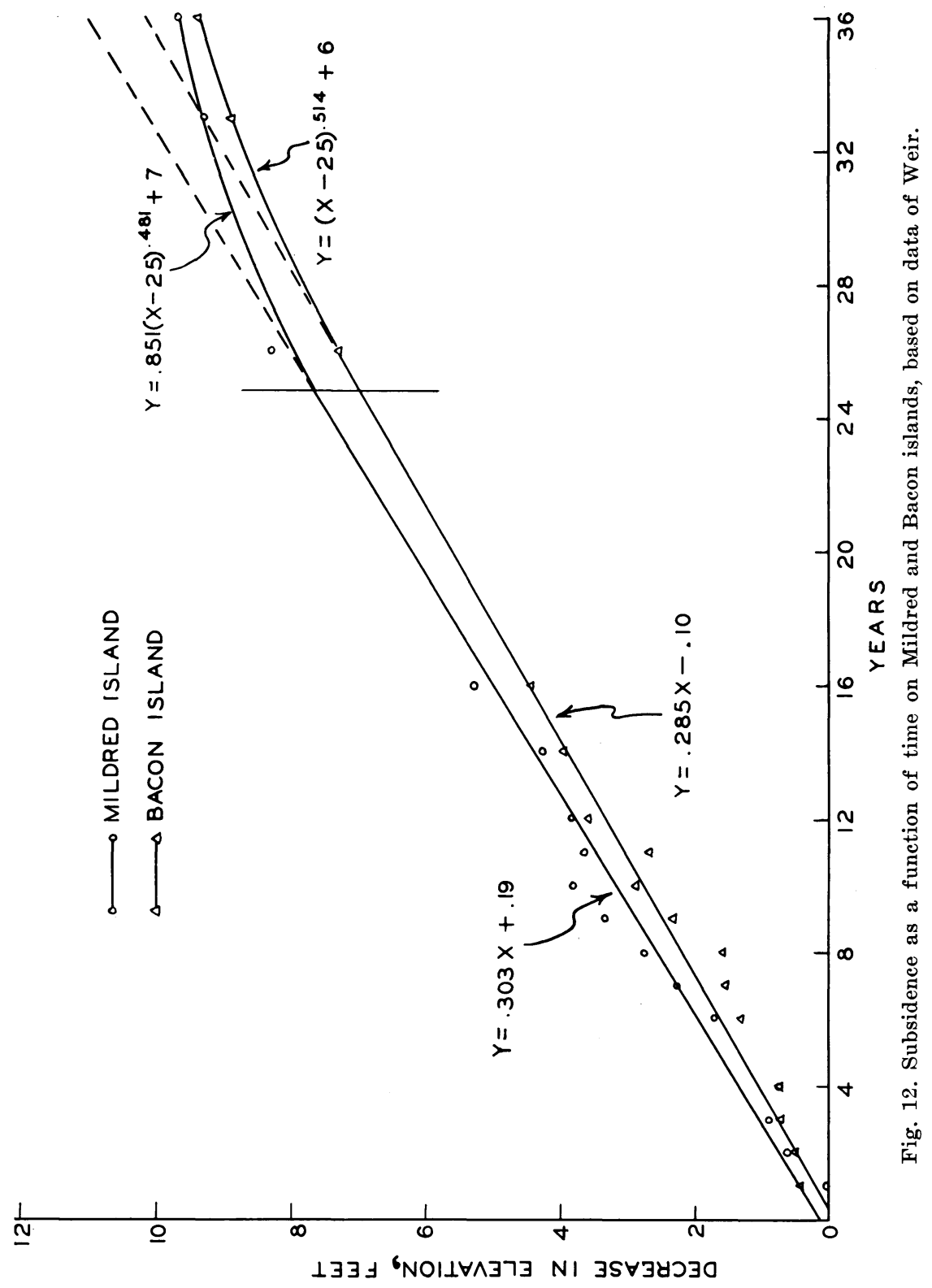


did have a measurable influence. It is worth-while recalling here the observation of Waksman and Stevens (1929) that available energy material is the limiting factor in peat decomposition. They found that addition of fertilizer salts such as phosphate and nitrate had no effect on decomposition, but removal of certain organic constituents by extraction with ether, toluene, or dilute hydrochloric acid enhanced the decomposition of the remaining material very markedly.

Correlation of the laboratory data with field measurements is difficult for a variety of reasons, including burning in the field, loss of soil by wind erosion, and difficulty in estimating the total depth of field soil which is undergoing decomposition. Certainly there is evidence here that anaerobic decomposition contributes to subsidence, and the total depth of subsiding soil may be considerable. Because of salt problems in the Delta area, growers have been advised to maintain the water table at the lowest practicable level, thereby aggravating the subsidence problem. In order to minimize subsidence it should be kept at the highest level consistent with good growth of the crop in question. Jongedyk et al. (1950) state that crops such as potatoes, corn, onions, carrots, celery, spinach, and table beets do well on muck soils with a water table of 22 to 26 inches, and that pasture and meadow crops do well with 15 - to 18 -inch water tables.

Deep cultivation unquestionably contributes to high subsidence rates because "buckskin," relatively undecomposed because of its saturated condition much of the time, is turned up and allowed to dry out considerably, so that aerobic decomposition occurs. Mixture of clay with organic soils apparently is ineffective as a means of decreasing subsidence rate.

On the basis of this study it is difficult to single out the particular factors responsible for the relatively high subsidence rates in the California Delta, but it seems likely that several are responsible. Moreover, the possibility exists that current rates of loss are less than they have been in the past.

Addition of plant residues to peat soils tends to counteract the effects of subsidence, even though amounts may not be sufficient to maintain a permanent elevation of the soil. As a means of conserving these soils, consideration might appropriately be given to management systems involving use of pasture. This achieves the purpose of maintaining the soil in an undisturbed condition with a high water table, and the extensive fibrous root system contributes substantially to the organic matter of the soil. 


\section{LITERATURE CITED}

Bingeman, C. W., J. E. Varner, and W. P. Martin

1953. The effects of the addition of organic materials on the biological decomposition of an organic soil. Soil Sci. Soc. Amer. Proc. 17: 34-38.

BIRCH, H. F.

1958. The effect of soil drying on humus decomposition and nitrogen availability. Plant and Soil 10: 9-31.

BroAdBent, F. E., and W. V. BARTholomeW

1948. The effect of quantity of plant material added to soil on its rate of decomposition. Soil Sci. Soc. Amer. Proc. 13: 271-74.

Broddbent, F. E., and A. G. Norman

1946. Some factors affecting the availability of the organic nitrogen in soil-a preliminary report. Soil Sci. Soc. Amer. Proc. 11: 264-67.

Chase, F. E., and P. H. H. GRAY

1957. Application of the Warburg respirometer in studying respiratory activity in soil. Canadian Jour. Microbiol. 3: 335-49.

Corbet, A. S.

1934. Studies on tropical soil microbiology: I. The evolution of carbon dioxide from the soil and the bacterial growth curve. Soil Sci. 37: 109-15.

Cosby, S. W.

1941. Soil survey of the Sacramenta-San Joaquin Delta area, California. USDA Bur. Pub. Inf. Series 1935, No. 21.

DARBY, H. C.

1940. The drainage of the Fens. Cambridge University Press.

Feustel, I. C., and H. G. Byers

1930. The physical and chemical characteristics of certain American peat profiles. USDA Tech. Bul. 214.

HALlam, M. J., and W. V. BartholomeW

1953. Influence of rate of plant residue addition in accelerating the decomposition of soil organic matter. Soil Sci. Soc. Amer. Proc. 17: 365-68.

JoNGedyk, H. S., R. B. Hickok, I. D. MAYER, and N. Ellis

1950. Subsidence of muck soils in Northern Indiana. Indiana Agr. Exp. Sta. Cir. 366.

NELLER, J. R.

1944. Oxidation loss of lowmoor peat in fields with different water tables. Soil Sci. 58: $195-204$.

Stephens, J. C.

1956. Subsidence of organic soils in the Florida Everglades. Soil Sci. Soc. Amer. Proc. 20: 77-80.

Stotzky, G., and J. L. MoRTensen

1958. Effect of addition level and maturity of rye tissue on the decomposition of a muck soil. Soil Sci. Soc. Amer. Proc. 22: 521-24.

Waksman, S. A., and E. R. Purvis

1932. The microbiological population of peat. Soil Sci. 34: 95-109.

WAKSMAN, S. A., and K. R. Stevens

1929. Contribution to the chemical composition of peat: V. The role of microorganisms in peat formation and decomposition. Soil Sci. 28: 315-39.

WEIR, W. W.

1950. Subsidence of peat lands of the Sacramento-San Joaquin Delta, California. Hilgardia 20(3) : 37-56.

Wilson, B. D. and E. V. STAKER

1933. The character of the peat deposits of New York. Cornell Univ. Agr. Exp. Sta. Memoir 149. 
The journal Hilgardia is published at irregular intervals, in volumes of about 600 pages. The number of issues per volume varies.

Subscriptions are not sold. The periodical is sent as published only to libraries, or to institutions in foreign countries having publications to offer in exchange.

You may obtain a single copy of any issue free, as long as the supply lasts; please request by volume and issue number from:

\section{Agricultural Publications 207 University Hall 2200 University Avenue Berkeley 4, California}

The limit to nonresidents of California is 10 separate issues on a single order. A list of the issues still available will be sent on request. 